\title{
Model Work Based Learning with the Concept Service Learning and Implementation for Improving the Motivation Learning and Outcomes Learning
}

\author{
${ }^{1}$ Luchyto Chandra Permadi, ${ }^{2}$ Dwi Agus Sudjimat, ${ }^{3}$ Tuwoso \\ ${ }^{1}$ Vocational education, State University of Malang, Indonesia \\ ${ }^{2,3}$ Faculty of Engineering, State University of Malang, Indonesia \\ luchy.chandra@gmail.com, agussudjimat@gmail.com, tusowoptk@yahoo.com
}

\begin{abstract}
The quality of skills and work attitude of vocational graduates is still in the eyes of the industry. Therefore, SMK is required to develop new environments and or innovative and interactive learning models that directly educate students to work by the 2013 Curriculum that focuses more on developing attitudes. Work Based Learning with the Concept of Services Learning through learning experiences. Use of learning model Teaching must be done by teachers from syllabus development up to RPP and implemented in classroom as well as in laboratory learning. Various empirical evidence shows the implementation of Work Based Learning with the Concept of Service Learning can improve learning motivation and learning output of vocational students significantly.
\end{abstract}

Keywords-model work-based learning with the concept or service learning; formatting; style

\section{INTRODUCTION}

The global era is full of developments and changes in various sectors of community life have an impact on the endurance will increase the quality of human resources. The human resources needed inside must have a spirit of competitiveness, adaptive and anticipatory, open to change, able to learn, easy, adaptable to new technology, and have broad base, strong, and basic capability to develop. In the RI Law no. Article 20 The year 2003 Article 15: Vocational education is education that is ready for learners for work in a particular field. Cheese education is a connected education, matching, human spirit to have a working habit to be able to enter and grow in the world of work (industry), so it can be used to improve his life.

The main characteristics of superior (XXI) workers (SDM) that must be balanced by SMK are workers who are competent in their field and characterized by the era of global era. The preparation of superior workers through SMK should be run by design. This means that in the work of learning, especially in vocational group learning (C2 and $\mathrm{C} 3)$, not only is it aimed at developing hard skills (cognitive and psychomotor skills) is also a worker character integrated into the learning concept [1]. Vocational education is related to the improvement of a person to work and by improving the training of potential labor. This includes various forms of education, training, or further training established to prepare someone for entry or not to work in a profession. It can be said that SMK is part of the national education system that can prepare skilled and knowledgeable personnel by the needs of employment opportunities and able to develop their potential in view and adapt to technological developments.

In the face of today's growing fragmentation, which is necessary in the development of labor is no longer merely the skills or automation of specialized units, the more important is the adaptability to present-day changes and future changes, an ability to accommodate change text context change (contextual change). For this adaptation power to form in the students, not enough to advance the component of labor with other components, will the work of work skills penetration that holistic and contextual. Coordination and effectiveness of the relationship of three academic skills, technical (occupational), and work skills (work skills) are very important subjects in instructional practice. With the basic capital of the graduates Receiving the world of work, technology and vocational education should be able to provide the stock as a whole as a benchmark achievement of learning practices.

The partnership relationship of vocational education institutions with the world of work in the implementation of learning is one way of vocational education institutions in reconfiguring their owned resources while utilizing various competencies owned by other parties. Vocational education in philosophy is an education that provides learning experiences, visual ranges, effective attention, cognitive information, or psychomotor skills that enhance individual vocational development processes to explore, define and maintain one's skills in the world of work. Vocational development is described as a process of development (cognitive, psychological, and effective) that includes the extension of a person from the stage of knowing and having a working idea toward a competent in achieving his life goals. In other words, the learning should try to get closer between education in school with the world of work.

Regarding subject matters, propositions can be proposed that students will learn best when they feel concerned in the subject-matter, and when concepts are applied in the context of everyday life, because students learn in fun and more 
challenging than learning in the form of components of the context-free Curriculum. Therefore, the challenge is how contextual learning provides an alternative way to improve the quality of student learning. In much of the contextual literature learning is defined as learning that allows students to learn to use their academic understanding and abilities in a variety of contexts within or outside the school to solve real-world or simulative problems, both alone and in groups [2]. One alternative learning model that can give the context of everyday life of students is the model of Work Based Learning with the concept of Service Learning.

Argues in general, Work Based Learning (WBL) should be used and implemented in vocational or vocational schools for several reasons, among others: 1) Work Based Learning (WBL) offers many opportunities to learn beyond traditional learning , 2) Work Based Learning (WBL) arises because of the demands to achieve higher quality, efficient and workrelated education, 3) Work Based Learning (WBL) is required due to the need for skills development of students for future employment, 4) Work Based Learning (WBL) is required due to the need for lifelong education and career-long education at work, and 5) Work Based Learning (WBL) is required due to the need for career development and professional development.

Suggests that Work-Based Learning (WBL) does not necessarily involve the workplace, it can involve simulated school work environments, where a reconstructive base of skills can be obtained using the Service Learning concept. Service Learning engages students in organizing academics and designing practical activities available to meet the needs of the community. Service-Learning emphasizes the potential of each student for positive change in society [3] and generates opportunities for joint development of technical, interpretive, and critical skills [3]

In this program, schools can conduct business activities either in the form of entrepreneurial networks, open school workshops, or also other business activities that are analyzing the needs that exist in the neighborhood around the school. In the service learning program, students under the guidance of teachers doing business activities in accordance with the competencies that students have. They do business activities after students and teachers read business opportunities that exist in the community.

In a simulated work environment for example, learners develop special skills and reconstruct practices in situations that symbolize actualization in the workplace. For example, students who undertook vocational studies as part of their school may see their activities conceptualized as Work Based Learning (WBL). Teachers can help individuals students to do work with those engaged in activities can include multiply connected conceptualizations and individual identity.

Motivation is the driving force that has become active, the motive of being active at a certain moment, even the need to achieve goals is greatly felt or undertaken. Motivator conscious effort to spur a person's behavior so that he was moved to do something that happened certain results or goals. The motivation initiated the flow of energy changes in each human. Motivation to learn can be seen regarding characteristics of student behavior related to interest, attention sharpness, ability to concentrate, emotional state, attitude, and habits.

Learning outcomes are "the result of the interaction of speech acts and student learning actions". Learning outcomes improve students' learning of the material taught by the teacher. "Learning outcomes are the results achieved from teaching and learning process in accordance with the purpose of education". The purpose of education at school.

\section{WORK-BASED LEARNING}

\section{A. Learning-Based Learning Model (WBL)}

The number of definitions expressed relates to the notion of Work-Based Learning. Often Work-Based Learning is exchanged with Work-Related Learning. Some definitions put forward Work-Based Learning are all forms of learning in the workplace, whether the form of work experience (work experience) or work in guidance (shadow work) within a certain time. Another definition states that WBL is all learning that is the result of workplace activities [4]

Work-based or Work-Based Learning (WBL) as a learning approach plays a role in promoting professional development and learning. WBL is used as a terminology in various countries for programs at school or college to gain experience from the world of work. It is also used for teenagers to be ready in the transition from school to work to learning the world of work or jobs and ready for the right choice in work .Another notion, states: "Work-based learning is any training that directly relates to the job requirements offered in your organization".

Defines the WBL program as "a process for recognizing, creating, and applying knowledge through, for, and at work that is part (credit) or all of the qualifications of higher education." [5] states that the WBL is a learning activity that cannot be separated from the context of learning organization or organization learning (learning organization).

Has one important point in WBL learning: (1) Identified learning, what knowledge is carried or owned by students in the WBL program, and what is expected of the program; (2) Learning is added, what new learning or knowledge will be provided in the program; (3) Introduction to learning, which students' knowledge they want after learning. (4) Learning equality, what academic equality to document as learning outcomes.

Thus, student motivation will become very important. Knowledge suggests that learning motivation can be examined from the point of view of student behavior characteristics related to interest, attention sharpness, concentration ability, emotional state, attitudes, and habits. Students who have high motivation in learning will show their great interest and full attention to their tasks and learning activities, tirelessly and wearily. Threatening to students who have low motivation, will show an attitude of reluctance, quickly bored, even avoid the desire to learn. Thus it is clear. This learning characteristic does not arise suddenly spontaneously, as it arises from 
learning, experience, self-study and work habits, and other attitudes.

\section{B. Objectives and benefits of Work-Based Learning}

Effective WBL preparation prepares learners in the world of work. The best combination of learning in the work of classroom, lab/workshop and workplace to be beneficial for all. Here are the benefits of WBL [2]

The WBL approach from the premise of learning arrangements to the real workplace context not only makes learning easier for students to digest and also increases involvement in industrial schools and workplaces [6] School activities support on-the-job development and learning while learners develop attitudes, knowledge, and skills from twoplace (school \& workplace industry) experiences and enable learning by real-life. [7]

Workplace learning "close relevance" between what is expected by DUDI and provided by vocational education. The gap occurs because there is a difference between what DUDI expects and the perception of academic ranks about what DUDI is expecting, should be closed with "solution 1" i.e. face-to-face communication with both parties with an agenda of how to overcome the low ability of graduates. "Solution 2" because the follow-up is not formed. DUDI in the preparation of the curriculum it is recommended that vocational education work together by involving DUDI directly. "Solution 3" as a step to overcome the discrepancy gap between the expected learning outcomes of vocational education and the expected DUDI business performance results is the implementation of the evaluation, the monitoring of apprenticeship through site visits by tutors and feedback from apprentices.

\section{Work Based Learning with the concept of Service Learning}

Service learning is a work-based learning activity where teaching-learning methods combine academic work with service. Students complete a series of planned activities and apply their skills and knowledge to help meet the needs of the school or the wider community. Service learning involves structured time for students to reflect on their service experience and may include recognition of student contributions. This is different from "community service" in emphasizing student learning as much as service to society. This is also generally an ongoing activity and not a one-time activity [8] Service learning involves students in organizing academics and designing practical activities available to meet the needs of their communities. The learning service emphasizes everyone's potential for positive change in society [9] and generates opportunities for joint development of technical, interpretive, and critical skills [3]

In this program the school can conduct business activities either in the form of entrepreneurial networks, open school workshops, or also other business activities that read the needs of the environment around the students themselves. In the service learning program, students under the guidance of teachers conduct business activities by the competence it has. They do business activities after students and teachers read the business opportunities that exist in the community.

\section{Syntax Model Work Based Learning}

WBL syntax consists of the following sequence: (1) Planning phase, covering: arranging job design. (2) Preparatory stage, including: preparing the forms to be used, approval and support documents, preparing work plan / career goals to be achieved, preparing students by: equipping students with relevant competencies (K3, passing $\mathrm{KD}$ required, orderly, have appropriate diploma, have interest in the job, have previous competency), and student competency mapping, if yes means to be eligible to continue on WBL implementation, otherwise students are returned at the preparatory stage, (3) according to the career field, at this stage the need for effective communication between teachers, workers appointed as assistants by DUDI, and parents, (4) Evaluation phase, evaluation conducted by: students themselves, teachers, DUDI. (5) Phase improvement and development of WBL outcomes, (6) Reporting and communicating phases and (7) Follow-up phase of the revised and developed WBL.

\section{E. The influence of work-based learning model with the concept of Service Learning to motivation and learning outcomes}

Alignment of Education with the World Work of comprehensive efforts to synchronize national education with the needs of the world of work, be line in the implementation. The success of educational alignment program with the world of work is determined by synergies between ministries and institutions or agencies related to the supply side.

Learning-based work will be full of inexpensive motivation to learn students of SMK, because of efforts to motivate the ability of soft skills and hard skills of students. This is reinforced by empirical evidence that shows the ability to speak English.

The empiric data is reinforced by data from several studies on work-based learning. the implementation of learning by using this module, shows the activity and motivation very high so as to improve student achievement of SMK. While in learning-based learning that has a significant effect on student achievement of SMK [10] Effective and practical work-based learning for teachers and instructors to assess student performance is more objective and can enhance cooperation between school and industry, especially student 'prakerin' student relations.

\section{F. Empirical Evidence Implementation of Work-Based Learning with the concept of Service Learning Improvement Motivation Student Learning SMK}

Work Based Learning with the concept of Service Learning will be a high motivation for learning SMK students, because the effort to motivate the ability of the cognitive, affective and psykomotor students. This is reinforced by empirical evidence showing learning. Work Based Learning with the concept of Service Learning to prove the increase in motivation of vocational students.

The power that drives a person to do something to achieve the goal and to achieve the required goals of some elements, 
which elements of his ability with motivation. Basic knowledge as a foundation that builds a person's interest because it arises the attitude that becomes the basis of motivation. From the description, it can be concluded that early knowledge has a dominant role in increasing motivation.

The empiric data is reinforced by data from several studies[9][[11] suggests, work Based Learning improves students' motivation in the learning process. Furthermore [14] Work Based Learning with the concept of Service Learning can increase the workforce of graduates in the employment sector. Working Learning with Service Learning concept can produce skilled graduates. Students with work-based learning model and have a high learning motivation that resulted in learning achievement of managing the highest product.

\section{G. Empirical Evidence Implementation of Work Based Learning Learning with Service Learning Concept for Increasing Students' Vocational Learning Outcomes}

Work Based Learning with Service Learning Concepts is closely related to improving student learning outcomes of SMK, because of the importance of learning in exploring the capabilities of the cognitive, affective and psychomotor aspects of vocational students. Implemented on the students in a row is the quality of Work Based Learning with the concept of Service Learning. To improve the learning result of Work Based Learning with Service Learning concept, all three factors must be considered and intensified in order to obtain satisfactory result in learning of Work Based Learning model with Service Learning concept. This finding is in line with various findings which stated that the quality of learning result is determined by the quality of the learning process teaching.

The teaching and learning process is characterized by the interaction of teachers/teachers with students. The quality of teacher and student interaction is determined by the readiness status of teachers/teachers to implement the learning process and readiness status of students in the learning process Intervention of learning quality, for example, by applying optimally problem-based learning has improved the students' learning outcomes. Likewise, improving the quality of learning with the method will improve the quality of learning outcomes.

[2][5] Concluded that when work-based learning was implemented with adequate staff or faculty support and evaluated correctly, the program would be positive. Furthermore [12] learning through work-based learning enables the connecting of learning with real-life work activities [13]. [9] and [3] argue that the WBL is able to bridge the gap between theory and practice. [6] Professional attitude, mental readiness work, and student independence is higher than the conventional class.

\section{CONCLUSION}

Work-Based Learning with Concept of Service Learning provides a variety of learning processes, in terms of learning motivation and student learning outcomes. Workplace learning experiences are implemented, refined, expanded in learning both in school and workplace and in service to the community. Continuous learning with the concept of Service Learning is one of the learning models are loaded with attitudes, knowledge, skills, behaviors, habits, and linkages through learning experiences. The use of learning-based learning model with Service Learning Concept should be implemented by teachers especially teachers in the field of vocational and development ranging from the development of syllabus to RPP and implemented in the classroom as well as in the learning of the laboratory. Various empirical evidence shows the result of English-based learning can improve learning motivation and student learning outcomes significantly

\section{REFERENCES}

[1] 2014:267 Sudjimat, "Mendesain pembelajaran kejuruan berkarakter pekerja di smk," vol. 37, no. 1, pp. 83-94, 2014.

[2] S. Fallows, G. Weller, S. Fallows, and G. Weller, "Transition from student to employee: a work- based programme for " graduate apprentices' in small to medium enterprises Transition from Student to Employee: a work-based programme for "graduate," vol. 6820, no. October, 2016.

[3] M. Ruth and H. Cqsw, "Work-based learning routes in social work education: an exploration of student experiences," 2015.

[4] J. Brennan and B. Little, "( A Centre for Higher Education Research and Information ) A Review of Work Based Learning in Higher Education," no. October, 1996.

[5] J. A. Raelin, "Work-based Learning: bridging knowledge and action in the workplace," vol. 7, no. 4, 2010.

[6] B. T. Siswanto and P. T. Otomotif, "MODEL PENYELENGGARAAN WORK-BASED LEARNING WORK-BASED LEARNING IMPLEMENTATION MODEL IN AUTOMOTIVE DIPLOMA III VOCATIONAL EDUCATION," no. 2, pp. 11-26.

[7] J. A. Chadd, M. A. Anderson, and M. A. Anderson, "Illinois WorkBased Learning Programs : Worksite Mentor Knowledge and Training," 2005.

[8] A. L. Review, F. O. R. Policy, S. Partners, I. N. Etf, and P. Countries, "WORK-BASED LEARNING :"

[9] D. Gray, “A Briefing on Work-based Learning,” no. 11, 2001.

[10] V. L. Hariyanto, "WORK BASED LEARNING ( WBL ) AT VOCATIONAL EDUCATION,” no. 3, pp. 132-136.

[11] M. R. Sattar, M. Y. Ruhizan, A. A. Ahmad, M. R. Mamat, H. Iskandar, and M. Yatim, "Instructors' Perception on the Implementation of WorkBased Learning Program in Automotive Industry," J. Asian Vocat. Educ. Train., vol. 7, no. 2013, pp. 22-31, 2014.

[12] A. B. N. R. Putra, W. Irdianto, A. Mukhadis, and S. Suhartadi, "Pocket Book Learning: Learning Methods to Train Students Productive and Creative Using 'BRANO' as an Effective Learning Recorder,' in Proceedings of the International Mechanical Engineering and Engineering Education Conferences (IMEEEC-2016), 2016, vol. 30034, p. 30034 . 